\title{
IMPLEMENTASI MODEL PEMBELAJARAN PENEMUAN (Discovery Learning Model) UNTUK MENINGKATKAN KETERAMPILAN BERPIKIR KRITIS DAN HASIL BELAJAR FISIKA DI SMAN 3 BENGKULU TENGAH
}

\author{
Rahayu Gustika, Indra Sakti, Desy Hanisa Putri
}

Program Studi S1 Pendidikan Fisika FKIP-UNIB

Email :rahayugustika95@gmail.com

\begin{abstract}
ABSTRAK
Penelitian ini bertujuan untuk meningkatkan aktivitas, keterampilan berpikir kritis dan hasil belajar siswa kelas X SMA Negeri 3 Bengkulu Tengah. Penelitian ini merupakan penelitian tindakan kelas (classroom action research) yang dilaksanakan dalam 3 siklus terdiri atas empat langkah, yaitu : 1) perencanaaan, 2) pelaksanaan tindakan, 3) observasi, dan 4) refleksi. Data hasil aktivitas dan keterampilam berpikir kritis siswa digunakan lembar observasi sedangkan data hasil belajar siswa digunakan tes hasil belajar dalam bentuk soal esai. Hasil penelitian diperoleh bahwa siklus I skor rata-rata aktivitas siswa 21,5 dengan kriteria cukup, siklus II 26 dengan kriteria baik dan siklus III 29,5 dengan kriteria baik. Pada siklus I nilai rata-rata persentase observasi keterampilan berpikir kritis siswa yaitu 50,54 \% dengan kriteria cukup, siklus II 73,99 \% dengan kriteria kritis , dan pada siklus III menjadi 85,99\% dengan kriteria kritis sedangkan hasil belajar yang diperoleh pada siklus I nilai rata-ratanya 75,3, pada siklus II menjadi 81,4, dan pada siklus III nilai rata-rata siswa adalah 84. Berdasarkan hasil penelitian dapat disimpulkan bahwa implementasi model discovery learning dapat meningkatkan aktivitas, keterampilan berpikir kritis dan hasil belajar fisika siswa.

Kata kunci : discovery learning, aktivitas belajar, keterampilan berpikir kritis, hasil belajar
\end{abstract}

\begin{abstract}
This study was aimed to increase activity, critical thinking skills and learning outcomes of class X SMA Negeri 3 Bengkulu Tengah. This research was a classroom action research whics conducted in 3 cycles consisting of four steps, namely: 1) planning, 2) action implementation, 3) observation, and 4) reflection. Data on the results of activities and skills in critical thinking students were used in observation sheets while data on student learning outcomes were used in the form of learning outcomes in essay test. The results showed that the first cycle average score of student activity was 21.5 with sufficient criteria, cycle II 26 with good criteria and cycle III 29.5 with good criteria. In cycle I the average value of observation percentage of students' critical thinking skills is $50.54 \%$ with sufficient criteria, cycle II $73.99 \%$ with critical criteria, and in cycle III it becomes $85.99 \%$ with critical criteria while learning outcomes were obtained in cycle I the average value is 75.3 , in cycle II it becomes 81.4 , and in cycle III the average value of students is 84 . Based on the results of the study it concluded that the implementation of discovery learning models can increase activity, critical thinking skills and learning outcomes student physics.

Keywords: discovery learning, learning activities, critical thinking skills, learning outcomes
\end{abstract}

\section{PENDAHULUAN}

Kegiatan pembelajaran merupakan suatu proses timbal balik ataupun interaksi antara guru dan siswa dalam proses pembelajaran. Guru merupakan salah satu faktor keberhasilan untuk mewujudkan tujuan pembelajaran, karena dalam proses pembelajaran guru dapat mempengaruhi dan membina siswa untuk dapat meningkatkan kecerdasan serta keterampilan siswa. Pada kurikulum 2013, siswa didorong untuk menjadi lebih aktif yaitu dimulai dari mengamati, menemukan sendiri, dan menyimpulkan sendiri dari suatu kegiatan ataupun pengalaman yang telah dilakukan. Sehingga dalam penerapan kurikulum 2013, guru hanya bertindak sebagai 
fasilitator dan motivator, namun pada akhir pembelajaran guru menyempurnakan perjelasan dari kegiatan yang telah dilakukan oleh siswa.

Data hasil pengamatan bahwa siswa kelas X IPA.5 SMAN 3 Bengkulu Tengah nilai pelajaran fisika yang diperoleh siswa masih berada pada standar KKM dan sebagian masih ada yang dibawah KKM yaitu 75. Siswa kelas X IPA.5 SMAN 3 Bengkulu Tengah berjumlah 30 siswa.Dilihat dari hasil nilai raport pada semester ganjil tahun pelajaran 2017/2018 nilai fisika tertinggi yang diperoleh siswa adalah 79 dan nilai terendah adalah 73.Dari 30 siswa di dalam kelas, sebanyak 19 siswa mendapatkan nilai standar KKM. Hal itu berarti 63,33\% siswa kelas X IPA.5 SMAN 3 Bengkulu Tengah mendapatkan nilai standar KKM. Selain itu nilai rata-rata pada pelajaran fisika kelas X IPA.5 SMAN 3 Bengkulu Tengah semester ganjil adalah 71,25. Selain nilai pelajaran fisika ada juga nilai keterampilan siswa.Nilai keterampilan tertinggi yang diperoleh siswa adalah 76 dan nilai keterampilan terendah adalah 70 . Nilai keterampilan rata-rata siswa kelas X IPA.5 SMAN 3 Bengkulu Tengah adalah 72,10.

Hasil observasi menunjukkan perlunya upaya untuk meningkatkan keterampilan berpikir kritis dan hasil belajar siswa. Menurut Arikunto (2009)[1] yang dimaksud dengan hasil belajar adalah suatu hasil ysng diperoleh siswa yang dinyatakan dengan bentuk huruf, angka, ataupun kata-kata setelah memalui proses pengajaran yang dilakukan oleh guru. Sedangkan Purwanto (2012) [2] menyatakan bahwa kemampuan berpikir sebagai sarana untuk mencapai tujuan pendidikan yaitu agar siswa mampu memecahkan masalah taraf tinggi. Wulandari (2016) [3] menjelaskan berpikir kritis merupakan keputusan yang masuk alal mengenai apa yang dipercayai dan apa yang dilakukan melalui sebuah tujuan proses. Salah satu upaya untuk mencapai tujuan pembelajaran sains khususnya fisika adalah dengan memilih model pembelajaran yang dapat memfasilitasi terjadinya komunikasi antara siswa dengan siswa dan guru dengan siswa, sehingga mampu menumbuhkan berpikir kritis siswa.Observasi yang telah dilakukkan menunjukkan masih ada siswa yang memperoleh nilai dibawah KKM ataupun standar KKM yang telah ditentukan oleh sekolah.Maka untuk mencapai tujuan pendidikan secara maksimal, peran guru sangat penting serta diharapkan guru mampu memilih model pembelajaran yang tepat dan sesuai dengan konsep-konsep pelajaran yang akan diajarkan. Sehingga nilai pelajaran fisika yang diharapkan dapat meningkat atau diatas KKM yang telah ditentukan oleh sekolah.

Model pembelajaran discovery learning merupakan salah satu model yang sesuai dengan kurikulum 2013. Menurut Nurudin (2016) discovery merupakan model pebelajaran yang melibatkan beberapa proses mental siswa untuk menemukan suatu pengatahuan (konsep dan prinsip) dengan cara mengasimilasi berbagai pengetahuan (konsep dan prinsip) yang dimiliki siswa. Dalam pembelajaran discovery, siswa didorong untuk aktif belajar dengan konsep-konsep dan prinsip-prinsip, dan guru mendorong mereka untuk memiliki pengalaman-pengalaman tersebut untuk menemukan prinsip-prinsip bagi diri mereka sendiri.Model pembelajaran ini memiki enam tahap yaitu meliputi stimulasi/pemberian rasangan, identifikasi masalah, pengumpulan data, pengolahan data, pembuktian, dan menarik kesimpulan [4].

Latar belakang sebagaimana diuraikan diatas, maka dipandang perlu melakukan penelitian yang berjudul "Implementasi Model Pembelajaran Penemuan (Discovery Learning Model)untuk Meningkatkan Keterampilan Berpikir Kritis dan Hasil Belajar Fisika di SMAN 3 Bengkulu Tengah(Penelitian Tindakan Kelas pada Konsep Usaha dan Energi di kelas X IPA.5)" dengan rumusan masalah (1) Bagaimana aktivitas belajar siswa melalui penerapan model pembelajaran penemuan pada materi usaha dan energi di kelas X IPA.5 SMAN 3 Bengkulu Tengah?, (2) Bagaimanakah keterampilan berpikir kritis siswa melalui penerapan model pembelajaran penemuan pada materi usaha dan energi di kelas X IPA.5 SMAN 3 Bengkulu Tengah?, dan (3) Apakah penerapan model pembelajaran penemuaan dapat 
meningkatkan hasil belajar siswa pada materi usaha dan energi di kelas X IPA.5 SMAN 3 Bengkulu Tengah?

Sesuai dengan rumusan masalah diatas, maka tujuan yang akan dicapai dalam penelitian ini adalah (1) Mendeskripsikan aktivitas belajar siswa dengan penerapan model pembelajaran penemuan pada materi usaha dan energi di kelas X IPA.5 SMAN 3 Bengkulu Tengah, (2) Mendeskripsikan keterampilan berpikir kritis siswa pada model pembelajaran penemuan materi usaha dan energi di kelas X IPA.5 SMAN 3 Bengkulu Tengah, dan (3) Menentukanhasil belajarsiswa dengan penerapan model pembelajaranpenemuanpada materi usaha dan energi di kelas X IPA.5 SMAN 3 Bengkulu Tengah.

\section{METODOLOGI PENELITIAN}

Penelitian ini adalah Penelitian Tindakan Kelas (ClassroomAction Research). Menurut Trianto (2012) ada empat tahapan penelitian tindakan kelas yaitu 1) perencanaan tindakan (planning), 2) pelaksanaan tindakan (acting), 3) pengamatan tindakan (observing), dan 4) refleksi tindakan (reflecting) [5].

Penelitian ini dilaksanakan di SMA Negeri 3 Bengkulu Tengah tahun ajaran 2017/2018.Subjek penelitianadalah siswa kelas X IPA.5 yang jumlahnya 30 siswa, terdiri dari 12 siswa laki-laki dan 18 siswa perempuan. Siswa dikelas ini bersifat heterogen atau memiliki kemampuan yang berbeda-beda.

Metode pengumpulan data dalam penelitian ini menggunakan metode tes untuk memperoleh data hasil belajar dan observasi untuk memperoleh data aktivitas dan keterampilan berpikir kritis siswa.Data tes yang digunakan berupa soal esai.Soal esai sebelum diberikan kepada siswa, soal terlebih dahulu divalidasi oleh validator.Untuk mendapatkan nilai hasil belajar digunakan rumus :

$$
\text { Skor }=\frac{\text { Skor Perolehan }}{\text { Skor Maksimal }} \times 100
$$

Skor data yang diperoleh dari seluruh siswa di hitung nilai rata-rata, standar deviasi, daya serap dan ketuntasan secara klasikal.Data observasi yaitu data aktivitas dan keterampilan berpikir kritis siswa.Persentase data observasi keterampilan berpikir kritis dapat dianalisis dengan menggunakan rumus :

$$
\text { Nilai }=\frac{\sum \text { skor perolehan }}{\sum \text { skor maksimal }} \times 100 \% \text {. }
$$

Kriteria yang digunakan yaitu apabila nilai keterampilan berpikir kritis siswa kurang dari $33,3 \%$ maka nilainya masih tergolong kurang kritis. Nilai yang berkisaran antara 33,4\% - 66,7\% tergolong cukup kritis, dan nilai 66,8\% - 100\% tergolong kritis (Sochibin, 2009) [6].

\section{HASIL DAN PEMBAHASAN}

Hasil penelitian yang di lihat adalah peningkatan aktivitas belajar, keterampilan berpikir kritis dan hasil belajar siswa menggunakan model pembelajaran discovery learning dengan pendekatan saintifik.Penelitian ini dilakukan dalam tiga siklus.Adapaun hasil yang diperoleh adalah sebagai berikut : 


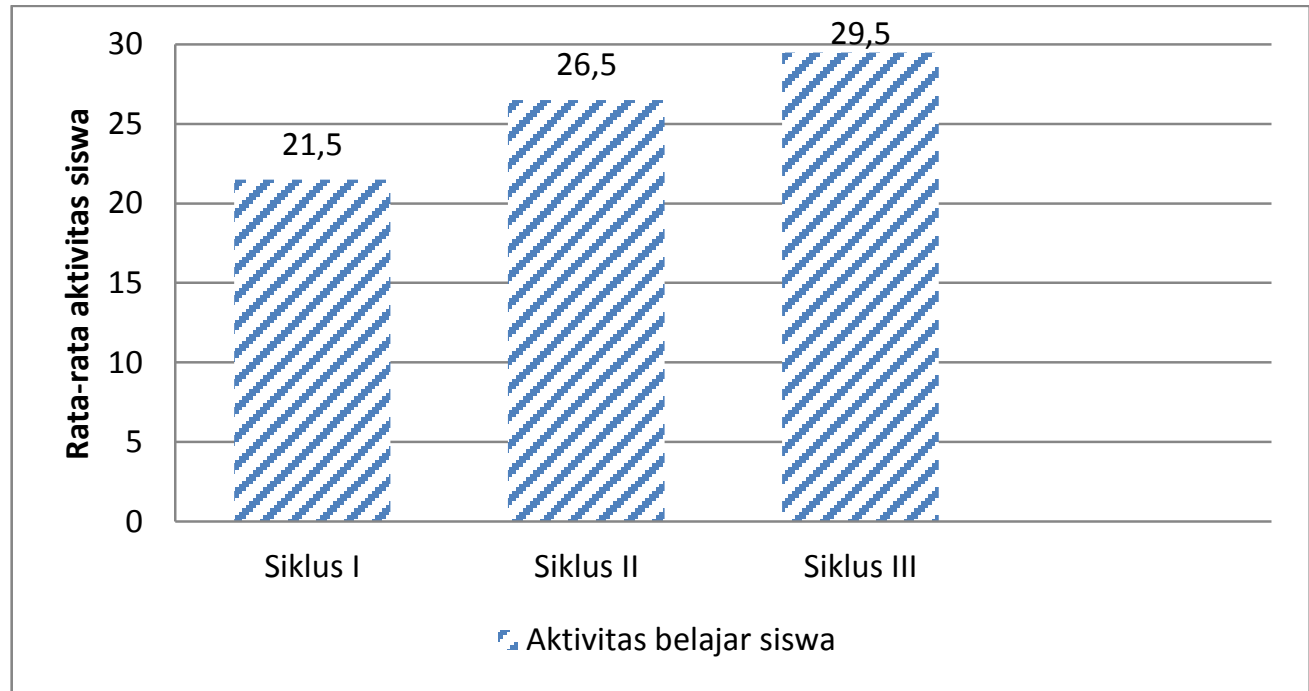

\section{Gambar 1. Grafik Perkembangan Skor Aktivitas Belajar Siswa}

Gambar1 menunjukkan bahwa aktivitas siswa pada siklus I memperoleh skor rata-rata keseluruhan yaitu 21,5 aktivitas siswa kemudian meningkat pada siklus II menjadi 26,5 kemudian mengalami peningkatan kembali pada siklus III menjadi 29,5. Aktivitas belajar yang diamati yaitu sesuai dengan langkah model discovery learning. Langkah discovery learning yaitu stimulus/pemberian rangsangan, identifikasi masalah, pengumpulan data, pengolahan data, pembuktian, dan menyimpulkan.

Kekurangan-kekurangan aktivitas siswa dalam mengikuti pembelajaran ini dianalisis dan dilakukan perbaikan dalam tiap siklusnya. Refleksi aktivitas siswa ini tertuang pada deskripsi hasil penelitian. Peningkatan aktivitas siswa ini tidak terlepas oleh peranan guru dalam membimbing, mengarahkan dan memotivasi siswa dalam belajar.Aktivitas belajar siswa dalam mengikuti kegiatan pembelajaran dengan menerapkan model pembelajaran discovery learningtelah mengalami perbaikan dan peningkatan. Karena semua proses kemampuan siswa dalam menemukan sesuatu sangat dikembangkan dalam poses pembelajaran ini.

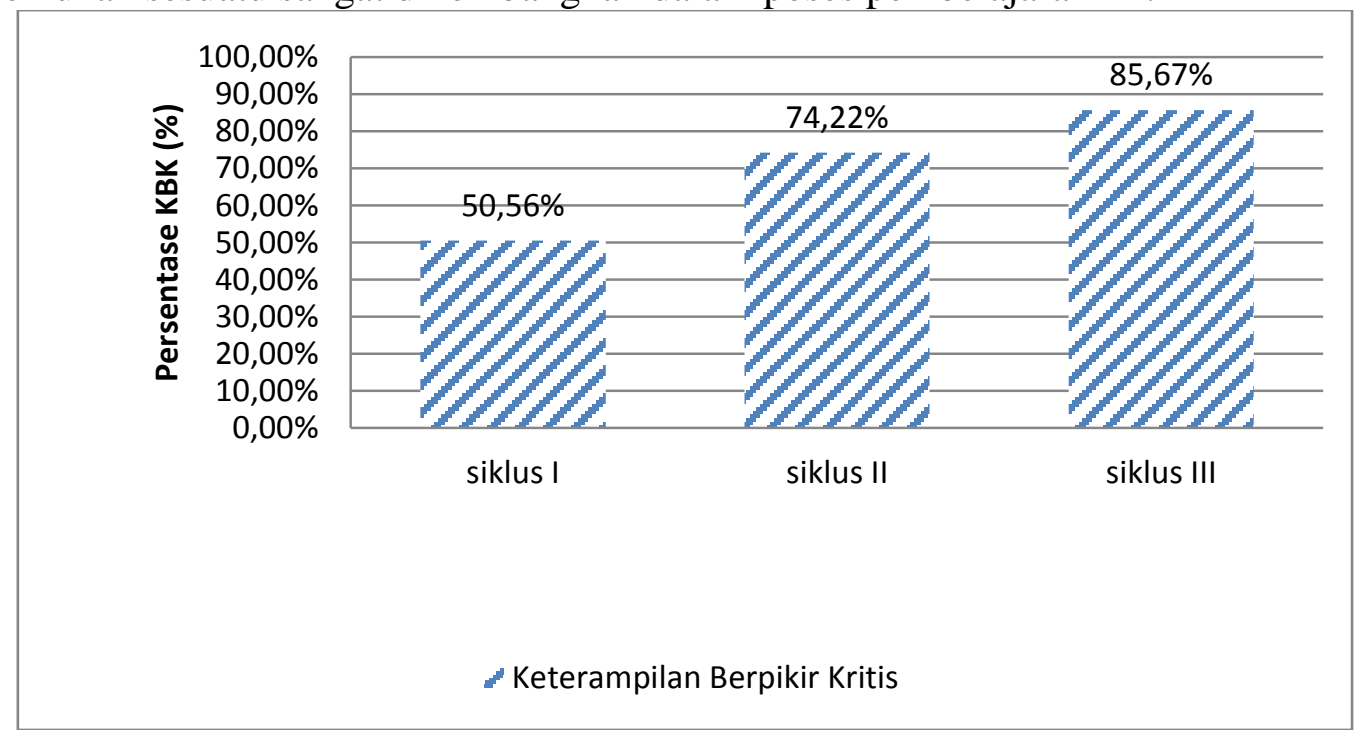

Gambar 2 Grafik Keterampilan Berpikir Kritis Siswa 
Gambar 2 menunjukkan bahwa keterampilan berpikir kritis siswa semakin meningkat pada setiap siklusnya. Pada siklus I persentase keterampilan berpikir kritis siswa adalah 50,56\% dengan kriteria cukup kritis. Pada siklus II keterampilan berpikir kritis siswa meningkat menjadi $74,22 \%$ dengan kriteria kritis. Sedangkan pada siklus III keterampilan berpikir kritis siswa meningkat menjadi $85,67 \%$ dengan kriteria kritis.

Peningkatan keterampilan berpikir kritis siswa terjadi karena telah dilatih pada setiap siklusnya dengan mengerjakan lembar kerja siswa (LKS) yang telah dibuat berdasarkan indikator ataupun aspek keterampilan berpikir kritis. Menurut Nengsi (2012) [7] indikator berpikir terdiri dari 12 indikator dan dikelompokkan menjadi 5 keterampilan dasar yaitu, memberi penjelasan dasar, membangun keterampilan dasar, menyimpulkan, membuat penjelasan lebih lanjut, dan strategi dan taktik. Hartati (2010) [8] menyatakan metode pembelajaran yang mempunyai karakteristik melibatkan siswa secara aktif adalah pemebelajaran penemuaan. Rangkaian kegiatan dalam proses pemelajaran penemuan merupakan aktivitas dalam berpikir kritis.

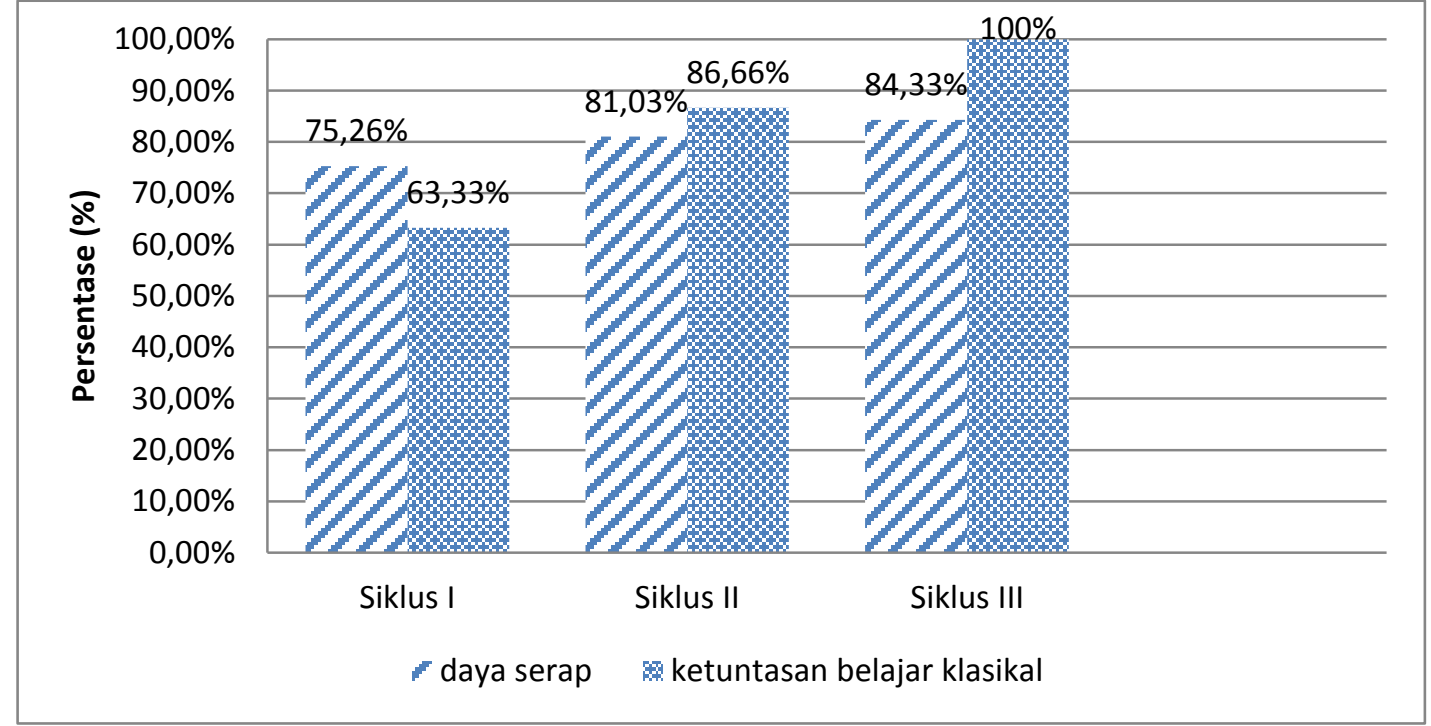

Gambar 3. Grafik Daya Serap dan Ketuntasan Belajar

Peningkatan tes siklus ini menggambarkan bagaimana peningkatan penguasaan siswa terhadap materi pelajaran yangmenujukkanbahwa penerapan model pembelajaran discovery learning berhasil meningkatkanhasilbelajarsiswa.Sesuai dengan teori Brunner yang menyarankan agar peserta didik belajar secara aktif untuk membengun konsep dan prinsip.Kegiatan discovery melalui kegiatan eksperimen dapat menambah pengatahuan dan keterampilan peserta didik secara simultan (Murfiah, 2017) [9].

\section{KESIMPULAN DAN SARAN}

Berdasarkan hasil penelitian dan pembahasan diperoleh kesimpulan sebagai yaitu (1) pembelajaran dengan menerapkan model pemebelajaran penemuan dengan pendekatan saintifik dapat meningkatkan aktivitas belajar siswa secara signifikan pada materi usaha dan energi di kelas X IPA.5 SMAN 3 Bengkulu Tengah terbukti pada siklus I aktivitas siswa dengan kriteria cukup, meningkat pada siklus II dengan kriteria baik dan meningkat lagi pada siklus III dengan kriteria baik, (2) pembelajaran dengan menerapkan model pemebelajaran penemuan dengan pendekatan saintifik keterampilan berpikir kritis siswa pada materi usaha dan energi di kelas $\mathrm{X}$ IPA.5 SMAN 3 Bengkulu Tengah pada siklus I keterampilan berpikir kritis siswa berkriteria cukup kritis, meningkat pada siklus II dengan kriteria kritis , dan meningkat lagi pada siklus III dengan kriteria kritis dan (3) pembelajaran dengan menerapkan model pemebelajaran penemuan dengan pendekatan saintifik dapat meningkatkan hasil belajar siswa pada materi usaha dan energi 
di kelas X IPA.5 SMAN 3 Bengkulu Tengah terbukti pada peningkatan nilai rata-rata pada setiap siklusnya.

Berdasarkan penelitian yang telah dilakukan, disarankan perbaikan penelitian dimasa yang akan datang yaitu (1) Penerapan model pemebelajaran penemuan (discovery learning model) sebaiknya diterapkan pada materi-materi tertentu yang sesuai, agar pembelajaran yang dilaksankan selaras antara model dan materi yang akan diajarkan dan (2) Untuk menunjang keberhasilan dalam penerapan model pembelajaran penemuan (discovery learning model) disarankan kepada pihak sekolah agar melengkapi dan menambah jumlah alat-alat pratikum Fisika agar pada kegiatan pembelajaran dapat dibagi menjadi kelompok belajar yang besar dan siswa lebih memahami materi yang sedang diajarkan.

\section{DAFTAR PUSTAKA}

[1] Arikunto, S. (2009). Penelitian Tindakan Kelas. Jakarta: Bumi Aksara.

[2] Purwanto, C. E., Nugroho, S. E., \& Wiyanto. (2012). Penerapan Model Pembelajaran Guided Discovery Pada Materi Pemantulan Cahaya Untuk Meningkatkan Berpikir Kritis. Unnes Physics Education Journal , 28.

[3] Wulandari, A. Y., Tanwil, M., \& Amin, B. D. (2015). Penerapan Pembelajaran Fisika Besrbasis Hands On Activities Untuk Meningkatkan Kemampuan Berpikir Kritis Siswa Kelas X MAN 2 Model Makassar. JPF, 211-213.

[4] Nurudin.S. (2016). Kurikulum Pembelajaran. Jakarta: RajaGravindo Persada.

[5] Trianto. (2012). Panduan Lengkap Penelitian Tindakan Kelas (classroom Action Research) Teori dan Praktik. Jakarta: Prima.

[6] Sochibin, D. \&. (2009). Penerapan Model Pembelajaran Inkuiri Terpimpin Untuk Peningkatan Pemahaman dan Keterampilan Berpikir Kritis Siswa SD. Semarang.

[7] Nengsi, S., S, B., \& A.Sopyan. (2012). Implementasi Model Pembelajaran Process Oriented Guided Inquiry Learning (POGIL) Untuk Meningkatkan Kemampuan Berpikir kritis Siswa. UPEJ , 44-52.

[8] Hartati. (2010). Pengembangan Alat Peraga Gaya Gesek Untuk Meningkatkan Keterampilan Berpikir Kritis Siswa SMA. Jurnal Pendidikan Fisika Indonesia .

[9] Murfiah, U. (2017). Pembelajaran Terpadu ( Teori \& Praktik Terbaik di Sekolah). Bandung: Refika Aditama. 